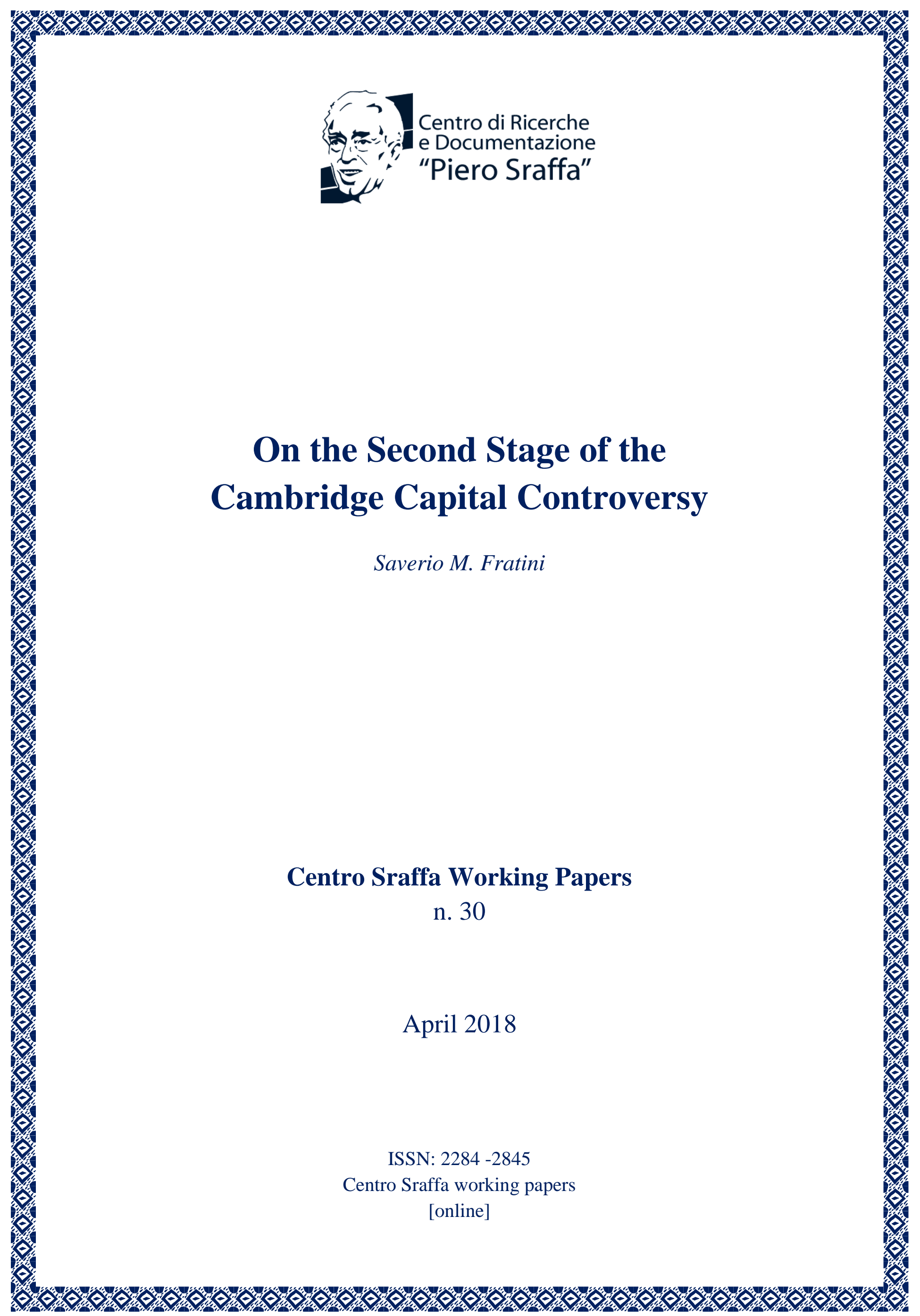




\title{
On the Second Stage of the Cambridge Capital Controversy
}

\author{
Saverio M. Fratini* \\ Roma Tre University
}

\begin{abstract}
The second stage of the Cambridge capital controversy concerns the neo-Walrasian theory of value and distribution. Since production is not understood in this theory as employing factors of production but rather commodities, i.e. goods and services with date and place of delivery, some scholars maintained that it is not affected by the problems that emerged, during the first stage of the controversy, as regards the conception of capital as a factor of production and the rate of interest as the price for its use.

The reply of the 'neo-Ricardians' was based on two arguments. The first regarded the relevance of the new notions of equilibrium adopted in the neo-Walrasian approach, with particular reference to temporary and Arrow-Debreu equilibria, and the second the possibility that the phenomena of re-switching and reverse capital deepening, by affecting the working of the saving-investment market, could cause equilibrium multiplicity and instability also in a neo-Walrasian framework.
\end{abstract}

Keywords: Cambridge capital controversy; neo-Walrasian theory; Arrow-Debreu equilibrium; saving-investment market

JEL codes: B51; D15; D25; D33; D50

\section{Introduction}

It is widely recognized that the Cambridge capital controversy falls into two stages. ${ }^{1}$ There are in fact two successive phases that can be distinguished with reference to the question involved.

During the first, which ideally spans the period from the publication of Sraffa's Production of Commodities (1960) to the symposium in the Quarterly Journal of Econom-

\footnotetext{
* For comments and suggestion received, thanks are due to C. Gehrke and A. Lazzarini. It goes without saying, the usual caveat applies.

${ }^{1}$ Cf., for instance, Garegnani (2010 and 2012) and Lazzarini (2015).
} 
ics of 1966, the point at issue concerned the explanation of the rate of interest as the price for the use of a special factor of production called 'capital'. As is known, the conclusion was that this conception of the interest rate is inacceptable because the factor of production 'capital' does not exist. ${ }^{2}$ In particular, every attempt to regard the total value of a set of heterogeneous capital goods as the quantity of a factor of production inevitably exposes the analysis to the risk of paradoxical results.

The second stage spans a decidedly longer period. ${ }^{3}$ It started with the GaregnaniBliss debate in the Review of Economic Studies in 1970 and has not yet arrived at any definitive conclusion, even though some results have been obtained.

This stage concerns the neo-Walrasian theory of value and distribution, in which, as is known, capital is not seen as a factor of production. In actual fact, this approach sees production processes not as employing factors of production, i.e. 'labour', 'land' and 'capital', but rather commodities, i.e. goods and services with specified dates and places of delivery. ${ }^{4}$ The neo-Walrasians therefore claimed that their theory of supply and demand was immune to the results obtained during the first stage by the 'neo-Ricardians', the economists who follow Sraffa's approach.

The neo-Ricardian reaction to this claim developed along two lines. The first regarded the significance of the notions of equilibrium adopted in the neo-Walrasian approach, with particular reference to temporary and Arrow-Debreu equilibria. The second instead concerned the possibility that the phenomena of re-switching and reverse capital deepening, ${ }^{5}$ by affecting the working of the saving-investment market, might bring about equilibrium multiplicity and instability in a neo-Walrasian framework as well.

The present paper seeks to address all these points. After a brief summary of the first stage of the controversy (section 2), it undertakes a reconstruction of the central features of the Garegnani-Bliss debate (section 3) and the neo-Walrasian approach (section 4). As regards the neo-Ricardian response, section 5 discusses the critique of the new notions of equilibrium. The argument about equilibrium multiplicity and instability caused by the saving-investment market is instead divided into two parts, one regarding ArrowDebreu models (section 6) and the other stationary models (section 7). Appendices A and $\mathrm{B}$ focus on technical aspects.

\footnotetext{
${ }^{2}$ Some scholars believe that the problem of capital concerns the right unit of measure of its quantity, but this is just a consequence of the problem. As capital is not a factor of production, there is no 'technical' unit of measure of its quantity.

${ }^{3}$ Another characteristic of this second stage is, as we shall see, the fact that the American side of the debate was no longer active and the controversy mainly involved, on both sides, scholars linked to Cambridge U.K.

${ }^{4}$ For the sake of simplicity, the possibility of different 'events' or 'states' in the moment of delivery is not considered in this paper.

${ }^{5}$ In order to avoid possible misunderstandings, 're-switching' is to be understood as the case in which the same set of production methods is in use for two different levels of the rate of interest but not for some levels between them, and 'reverse capital deepening' as the case in which an increase in the rate of interest (relatively to the wage rate) leads to a rise of the investment of capital per unit of labour.
} 


\section{The first stage of the controversy: a summary}

The debates about the notion of capital are as old as its marginalist conception as a factor of production. Cambridge (U.K.) economists began to be involved in these controversies since the 1930s, with the contributions by Sraffa (1932) and Kaldor (1937). However, even though some precedents can be found in Robinson's and Champernowne's articles of 1953 and especially the Corfu conference of $1958,{ }^{6}$ what we call the 'Cambridge capital controversy' actually started with the publication of Sraffa's Production of Commodities by Means of Commodities (1960), followed two years later by Samuelson's article on the 'surrogate' production function. ${ }^{7}$

Making reference to a 'persistent position' of the economy, characterised by stationary relative prices and a uniform rate of profit among sectors, ${ }^{8}$ Sraffa showed in his book that the link between relative prices and distribution variables, the wage rate and the profit rate in particular, can be complex and unpredictable. For example, in the event of a change of distribution in a certain direction, such as a continuum rise in the rate of profit, the relative price of two commodities may rise and fall in alternating stretches (cf. Sraffa 1960, p. 38, fig. 3).

This result, as Sraffa pointed out (1960, p. 38), actually deprived of any significance the claim that different methods of production of the same commodity can be understood as involving higher (or lower) 'capital intensity', as though this were a property of technical nature. Precisely because the prices of capital goods depend on the wage rate and the profit rate, the order of production methods on the basis of their employment of capital per unit of labour could, in general, vary as income distribution changes. The process initially with the lowest capital intensity can become the one with the highest capital intensity for different levels of the distribution variables. It is thus evident that the role of capital does not derive from the technical condition of production but rather from the social and institutional framework within which production processes take place.

One of the pillars of the neoclassical/marginalist theory of distribution thus collapsed, namely the idea that capital should be regarded as a factor of production, i.e. as an input, on a par with labour so as to justify a symmetrical explanation - in terms of

\footnotetext{
6 The International Economic Association held a conference in Corfu (Greece) on the theory of capital in 1958. A number of very important economists took part, including Sraffa. For a record of the conference, see Hicks (1960) and Lutz and Hague (1961).

${ }^{7}$ Actually, in his essay in honor of Åkerman, published in 1961, Samuelson already mentioned Sraffa's book among the relevant contributions to the theory of capital (cf. Samuelson 1961, p. 422).

8 This 'normal' or 'long-run' position has constituted the ideal framework for recognition of the persistent determinants of commodity relative prices since Adam Smith's time. It was only recently, as we shall see below, that this method was abandoned with the advent of the neo-Walrasian notions of equilibrium. We shall return to this point in section 5 .
} 
supply and demand - of the rate of interest (the general rate of profit) and of the wage rate, both understood as factor prices. ${ }^{9}$

Just two years after the publication of Sraffa's book, Samuelson (1962) tried to put forward a reply. Referring to a model in which the same consumption good can be obtained by means of many alternative techniques, each characterised by the employment of capital goods of a specific kind, he attempted to prove the existence of a special substance, a sort of 'jelly', able to take the shape of every possible kind of capital good and from which capital goods derive their productive power. If such a jelly existed, the employment of capital goods would be merely apparent: every time there is a change in the technique in use that implies a greater (net) output per unit of labour, this must be due to an increase in the amount of jelly embodied in the capital goods employed per unit of labour, whichever their kind.

Since the optimal technique for firms depends on the rate of interest, Samuelson's attempt would have worked if he had been able to prove that a fall in the rate of interest necessarily led to the use of techniques that, for the same amount of labour, employ a greater amount of jelly and give a greater (net) output. Levhari's contribution (1965) appeared to work precisely to this end, arguing that a technique adopted for a certain interest rate and then abandoned when the rate falls cannot be switched on again at a lower interest rate. He thus claimed that the re-switching of techniques is impossible.

As unequivocally established in the 1966 symposium $^{10}$ in the Quarterly Journal of Economics, however, Levhari's theorem was incorrect. Pasinetti and Garegnani, two economists of the Anglo-Italian school that took Sraffa as its point of reference, as well as Morishima and Sheshinski ${ }^{11}$ were able to prove by means of suitable counter-examples that re-switching is indeed possible despite Levhari's arguments to the contrary.

The possibility of re-switching was sufficient to make Samuelson's construction collapse. The fact that the same (optimal) production technique of the final good can be adopted for two different levels of the interest rate but not some levels between them definitely proved the groundlessness of the idea of the existence of 'capital' as a factor of production to be employed together with labour in variable proportions, and hence also of the rate of interest as the price to pay for its use. As Samuelson himself admitted in the final paper of the symposium:

the simple tale told by Jevons, Böhm-Bawerk, Wicksell, and other neoclassical writers-alleging that, as the interest rate falls in consequence of abstention from present

\footnotetext{
${ }^{9}$ The conception of the rate of interest as the price that brings the supply of and demand for capital into equilibrium is typical of almost all the traditional versions of the neoclassical/marginalist theory. For example, Marshall explicitly writes that 'interest, being the price paid for the use of capital in any market, tends towards an equilibrium level such that the aggregate demand for capital in that market, at that rate of interest, is equal to the aggregate stock forthcoming there at that rate' (Marshall [1890] 1920, p. 534).

${ }^{10}$ In actual fact, the subjects of the symposium were already addressed during the first conference of the International Econometric Society, held in Rome in 1965, where Pasinetti presented an initial version of his 1966 article.

${ }^{11}$ Cf. Bruno, Burmeister, and Sheshinski (1966), Garegnani (1966), Morishima (1966), and Pasinetti (1966).
} 
consumption in favor of future, technology must become in some sense more 'roundabout,' more 'mechanized,' and 'more productive' - cannot be universally valid. [Samuelson 1966, p. 568.]

Moreover,

There often turns out to be no unambiguous way of characterizing different processes as more 'capital-intensive,' more 'mechanized,' more 'roundabout,' except in the ex post tautological sense of being adopted at a lower interest rate [p. 582.]

This was the end of the idea of capital as a factor of production, at least outside the models in which the existence of just one commodity is assumed. There is no 'ultimate substance' or 'jelly' from which capital goods derive their productivity and the only thing that can take the shape of every possible set of capital goods is the amount of purchasing power that pays their prices.

\section{The Garegnani-Bliss debate in the Review of Economic Studies}

Once this had been established, any neoclassical economists wishing to go on regarding the interest rate as a price set by the supply of and demand for capital would have been faced with the problem of the possible 'reverse capital deepening', i.e. a fall, instead of a rise, in the demand for capital (for a given employment of labour) when the rate of interest decreases. Reverse capital deepening could therefore be seen as a possible cause of equilibrium instability.

This critical argument was used by Garegnani in an article published in 1970 in the Review of Economic Studies (Garegnani, 1970a). For reasons to be discussed below, this can be regarded as the ideal dividing line between the first and second stages of the Cambridge capital controversy.

It was in this article (pp. 425-26) that Garegnani indicated the re-switching of techniques and reverse capital deepening as possible causes of equilibrium instability. ${ }^{12} \mathrm{He}$ developed the argument in a peculiar way, however, by starting from an equilibrium position and assuming an increase in capital supply due to positive net savings. This means that there is now an excess supply of capital at the initial level of the interest rate, which starts to fall accordingly. The fall in the rate of interest is supposed to cause an increase in the demand for capital, but the opposite takes place in the event of reverse capital deepening: the demand for capital decreases and the excess supply can become even greater. Garegnani concludes as follows:

we are forced to the conclusion that a change, however small, in the 'supply' or 'demand' conditions of labour or capital (saving) may result in drastic changes of $r$ and $w$.

\footnotetext{
12 An extremely vague mention of the possibility that the reverse capital deepening may affect equilibrium instability is also found in Samuelson (1966, p. 578). In particular, Samuelson wrote that stability and uniqueness problems could arise in Modigliani's life-cycle model or in a 'Solow-Harrod growth model.'
} 
That analysis would even force us to admit that $r$ may fall to zero or rise to its maximum, and hence $w$ rise to its maximum or to fall to zero, without bringing to equality the quantities supplied and demanded of the two factors. [Garegnani 1970, p. 426]

Even though Garegnani clarified his position and reformulated this point in several papers (see in particular Garegnani 1983 and 1990), it is unclear, in the passage quoted above, whether the problem he intended to raise concerned comparative statics, equilibrium stability or even the very existence of equilibrium.

It was in the last sense that Bliss (1970) understood it in his comment on Garegnani's article published in the same journal, which was, as a result, mainly grounded on the existence proof of equilibrium for Arrow-Debreu models. As he wrote at the beginning,

Professor Garegnani in his paper makes a claim which, to economists familiar with the modern theory of general equilibrium, will seem rather surprising. He supposes an economy with many capital goods in stationary long-run equilibrium at rate of interest $r^{*}$. He then asks himself whether, following a change in demand leading to "a tendency to positive saving", there exists a new equilibrium of supply and demand consistent with the new demand functions. He concludes that no such equilibrium need exist ( $p$. [4]25-28). Now an equilibrium of supply and demand certainly might not exist, but we know from the work of G. Debreu [1959] that the conditions required for existence are rather weak, and that existence can be guaranteed whenever demand functions are continuous and the technology a convex one (e.g. a linear technology). Both these conditions obtain in Garegnani's model. How then does he arrive at his conclusion? [Bliss 1970, p. 437 $]^{13}$

According to Bliss, Garegnani obtained his result because he focused on 'stationary long-run equilibria' and, by so doing, failed to perceive the possible existence of equilibria in which relative prices and the rate of interest change over time. While Bliss's point will be addressed at a later stage, the important thing to stress for the moment is that both of the primary features characterising the second stage of the capital controversy were introduced in the Garegnani-Bliss debate: i) re-switching and reverse capital deepening were indicated as possible causes of equilibrium instability; ii) attention shifted to the neo-Walrasian models, where capital is not understood as a factor of production and the rate of interest as the price for its use.

\footnotetext{
${ }^{13}$ It can be noted in passing that Bliss's argument is incorrect, as Garegnani was not in fact referring to the same model as Debreu (1959). As Bliss himself wrote in the first part of the passage quoted, Garegnani was considering an economy 'in a stationary long-run equilibrium'. To be more precise, he addressed a traditional model in which the rate of interest is understood as the price that brings the supply of and demand for capital into equilibrium. This idea, as we shall see in the following sections, is totally absent in Arrow-Debreu models.

Accordingly, in his reply to Bliss's comment, Garegnani explicitly claimed that his analysis did not deal with Arrow-Debreu economies (cf. Garegnani, 1970b).
} 
Moreover, in this second stage, only one Cambridge was involved: the one in England. The neoclassical side of the controversy was no longer represented by Samuelson and the other MIT economists, who were replaced by Bliss, Hahn, ${ }^{14}$ and, some years later, Mandler.

\section{Neo-Walrasians vs. neo-Ricardians}

As seen in section 2, the results obtained in the first stage of the controversy concerned the view of capital as a factor of production and the rate of interest as the price for its use. They therefore left the neo-Walrasian theory of value essentially untouched, as these erroneous conceptions are no part of it.

The neo-Walrasians therefore proclaimed with great emphasis that their supply-anddemand explanation of commodity prices is not affected by the Sraffian - or neoRicardian, as they prefer to say - critiques of the neoclassical/marginalist theory of capital. In particular, Bliss (1975) and Hahn (1975 and 1982) maintained that in neoWalrasian general equilibrium models, starting from given initial endowments of commodities and assuming complete current and forward markets opened simultaneously at the initial date, it is possible to arrive at the determination of the intertemporal price system with no need to aggregate capital goods either in value terms or by means of any special 'jelly'. Moreover, they claimed that the critical arguments used by the neoRicardians were aimed at naïve versions of the theory, those appropriate for first-year students, which are aggregated for the sake of simplicity, but have no impact on more sophisticated versions such as the neo-Walrasian. In Hahn's words:

The neo-Ricardians, by means of the neoclassical theory of the choice of technique, have established that capital aggregation is theoretically unsound. Fine. Let us give them an alpha for this. The result has no bearing on the mainstream of neoclassical theory simply because it does not use aggregates. It has a bearing on the vulgar theories of textbooks. But textbooks are not the frontier of knowledge. [Hahn 1975, p. 363]

On the one hand, the neo-Walrasians therefore admitted, as Samuelson had already done in his summing-up of 1966, that the factor of production 'capital' does not exist, or at least that its existence is 'theoretically unsound'. It can have a place only in 'the vulgar theories of textbooks'. ${ }^{15}$ They were also aware that this particular factor of production was invented with the aim of explaining the rate of interest as the price for its use. As Bliss writes:

\footnotetext{
${ }^{14}$ Bliss was at Christ's College, Cambridge, when he wrote his comment on Garegnani's article and Hahn, as is known, spent most of his professional life in Cambridge.

15 Surprisingly enough, Hahn appears to put the aggregate textbook model and the one-commodity model on the same footing in his article of 1982 (see p. 370). This is somewhat dangerous, as the latter is in fact simply based on the very special and unrealistic assumption of the presence of just one kind of capital good. The former instead entails the conception of capital as a factor of production with all the attendant logical difficulties.
} 
It is true, of course, that capital, meaning here the physical goods which are used in capitalistic production, is typically held by its owners as a store of wealth and a source of income. But it does not follow that the economic theorist should regard it exclusively in this light. Wherein lies the temptation to do so? It is to be found in a closely associated view; namely, that the rate of interest is the price of capital. The value which accrues from a sale is the product of price and quantity sold. Hence if the rate of interest is the price of capital, the quantity of capital must be the wealth on which an interest yield is calculated. It will be shown shortly why this view is incorrect, but to cut a long story short, the conclusion may be announced at once. The rate of interest is not the price of capital. [Bliss 1975, pp. 6-7.]

On the other, however, they wanted to defend the supply-and-demand explanation of value and distribution. In particular, Hahn (1982) argued by means of a two-period and two-good example that the results (existence and Pareto-efficiency) obtained for the Arrow-Debreu equilibrium were 'not based on any aggregation hypothesis' (p. 371) and therefore not at risk. He thus drew the following conclusion:

unless one wishes to claim that aggregation is essential if a theory is to be called neoclassical, so that Arrow-Debreu for instance are not neoclassical, none of this [i.e. the neo-Ricardian critique] has any bearing on the main issue of this lecture. Sraffa performed a service in showing how neoclassical arguments can be used to show neoclassical aggregation parables to be in logical difficulties. But that cannot help with a critique of marginal theory. [Hahn 1982, p. 373]

The Sraffian economists' response to Bliss's and Hahn's claims developed along two distinct lines. The first, which will be considered in the next section, concerned the significance of the new neo-Walrasian notions of equilibrium, with particular reference to Arrow-Debreu equilibrium. The second, addressed in sections 6 and 7, sought instead to show the need, also in neo-Walrasian models, for a specific market of savings and investments that is actually analogous, at least as regards the problems that can arise there, to the market of the factor 'capital' in the traditional version of the neoclassical/marginalist theory.

\section{The new notions of equilibrium}

Theories of value have traditionally focused attention on a price system understood as the centre around which the prices that regulate actual trade gravitate. This idea represented, and indeed still does, the only possible link between reality, i.e. the prices determined in any trade session of a mercantile exchange, and one of the most abstract parts of economic theory, namely the theory of value.

At a later time, with the rise of the neo-Walrasian approach, new notions of equilibrium were introduced. Here we refer in particular to temporary and Arrow-Debreu equilibria, in both of which commodities delivered at different dates typically have different relative prices. In the temporary equilibrium model, markets are open at the beginning of each period and agents take their decisions - consumption and production plans - on 
the basis of their expectations about the prices that will regulate trading when the markets reopen in future periods. In the Arrow-Debreu model, markets for every present and future delivery are instead open at the beginning of the first period only and never reopen, so that every problem about future-price expectations is avoided by assumption. ${ }^{16}$

Since these equilibrium models are not designed to determine the central level around which actual prices tend to gravitate but rather different commodity prices for every possible date of delivery, the above-mentioned link between theory and reality breaks down.

Within the traditional conception, theoretical prices are generally different from the actual ones observed at different dates, and this is perfectly compatible with the tendency of the latter to orbit around the former. If instead, as in the neo-Walrasian approach, equilibrium is formed by prices of goods and services delivered period by period, then there is no possibility of the adjustment (or tendency) of actual prices towards theoretical ones. In the case of the Arrow-Debreu model in particular, either the actual prices of the commodities delivered at a certain date, say period $t$, correspond through some coincidence to those initially determined by equilibrium for delivery at that date, or the next date, $t+1$, will arrive and the actual and theoretical prices for delivery in $t$ will definitively remain different. In other words, since adjustment or gravitation processes take time, they do not appear to be possible with reference to prices of commodities with specific delivery dates. ${ }^{17}$

This problem was initially mentioned by Malinvaud, who wrote that, in the ArrowDebreu framework, '[t]here might be some difficulties with stability since time must then enter both the definition of equilibrium, and the process of convergence toward equilibrium' (Malinvaud 1961, p. 152). The point was, however, first raised by Garegnani during a conference held in 1974 at the State University of New York in Buffalo, the proceedings of which were published in 1976. In particular, Garegnani argued that the abandonment of the traditional method due to the rise of the neo-Walrasian approach took place at the expense of the relevance of the theory of value, which became

\footnotetext{
16 The reader might think that this assumption is irrelevant because 'if markets were reopened at later dates for the same Arrow-Debreu commodities, then no additional trade would take place anyway' (Geanakoplos 1987, p. 122). It is not so simple, however, because if agents knew that markets would open again, they would behave differently from the outset and all the problems connected with expectations and speculative trades, upon which a vast literature exists, would arise. These problems are instead completely avoided within the Arrow-Debreu framework.

17 Another problem, stressed by Petri (2004, pp. 67-71, and 2017), concerns the 'impermanence' of the data on which the equilibrium is determined. While trades at disequilibrium prices are not permitted in the traditional process of tâtonnement, they cannot be excluded if the adjustment process is to have something to do with reality. Trading at disequilibrium prices, agents reallocate their endowment in an unpredictable way. As a result, the equilibrium price system, depending on the distribution of initial endowments across households, changes during the process of adjustment.
} 
a kind of intellectual toy devoid of any importance for the analysis of reality. ${ }^{18}$ Garegnani's point was then taken up and developed by Petri (1978) a few years later. ${ }^{19}$

Moreover, Garegnani (1976, 1990 and especially 2010 and 2012) claimed that the difficulties encountered by the traditional marginalist theory with reference to capital as a factor of production were indeed at the origin of the neo-Walrasian drift. ${ }^{20}$ In his view, a central part in determining this turning point was played by Hicks. As is known, Hicks's initial attempt in his Theory of Wages (1932) to develop an explanation of income distribution based on the substitutability (at the margin) between production factors had met with strong objections due to the particular nature of the factor 'capital'.

In a well-known review of the book, Shove (1933, pp. 470-71) claimed that Hicks neither gave an appropriate definition of capital nor said how quantities of that factor are to be measured, and that it would therefore be impossible to follow his reasoning until those points had been cleared up. These criticisms prompted Hicks to rethink his approach radically and embark on a new path in Value and Capital ([1939] 1946).

On the one hand, this involved taking up some features of the theory put forward by Walras, one of the founders of the marginalist approach. We refer in particular to the given endowment of commodities taken by Walras as the starting point for his supplyand-demand analysis of value and distribution instead of the given quantities of the factors of production (labour, land, and capital) on which the initial versions of the theory were mostly based.

On the other, however, since this arbitrary endowment of commodities is generally incompatible with the persistency (stationarity) of the system of relative prices, ${ }^{21}$ Hicks was forced to abandon the traditional idea of equilibrium as a centre of gravitation and adopt a new conception in which relative prices are allowed to change at every possible date of delivery. He thus introduced the notions of temporary equilibrium, in particular, but also of 'equilibrium over time', which corresponds to the modern Arrow-Debreu equilibrium. ${ }^{22}$

18 That is sometimes admitted even by neo-Walrasian authors, who say that the Arrow-Debreu equilibrium is just a benchmark against which the real economy can be measured and not a position towards which it tends in the long run (see for example Geanakoplos 1987, p. 117).

${ }^{19}$ Similar arguments can also be found in Garegnani (1990), Currie and Steedman (1990), Petri (1991), (2004) and (2017) and Kurz and Salvadori (2003).

${ }^{20}$ For the origin of the new notions of equilibrium, see also Millgate (1979) and Gehrke (2003).

${ }^{21}$ Criticism of the Walrasian theory of equilibrium with capital formation lies beyond the scope of the present paper. Interested readers are therefore referred to Garegnani (1990, pp. 11-23) or to Fratini (2017) for a simplified analysis.

${ }^{22}$ According to the reconstruction provided by Petri (1991), after the publication of the second edition of Value and Capital (1946), Hicks himself became gradually aware of the limitation of the 'temporary equilibrium method'. In particular, Petri argues that, in Capital and Growth (1965), Hicks included the incompatibility with a time-consuming process of adjustment among the 'serious defects' of the temporary equilibrium method. 


\section{Saving-Investment equilibrium: part one}

As mentioned at the end of section 4, the second argument introduced by Garegnani and some other economists ${ }^{23}$ in response to Bliss and Hahn was based on the possibility that the phenomena of re-switching and reverse capital deepening would bring about equilibrium multiplicity or instability in neo-Walrasian models as well even though they do not regard capital as a factor of production. The basic idea of this argument was that neo-Walrasian equilibria would require equality between savings and investments for each period. Investments being understood as the value of the capital goods demanded by firms, the problems affecting the demand for capital in value terms could therefore arise again through the investment function or curve.

Garegnani presented this point in a number of seminars, conferences and papers (see in particular Garegnani 2000, 2003 and 2011), in which his analysis refers primarily to the model introduced by Hahn in his article of 1982, an Arrow-Debreu model with two commodities and two dates of delivery. ${ }^{24}$ There is no produced input and the initial endowments of commodities delivered in the first period (period 0) are partly consumed directly by households in that period and partly employed by firms, along with the endowment of labour, in order to produce consumption goods delivered in the second period (period 1).

For each commodity delivered in 0, Garegnani defines the amount 'saved' as the difference between its endowment and the quantity directly consumed. Savings are thus understood by Garegnani as the value of the quantities of commodities 'saved'. He instead defines investments as the value of the commodities that firms wish to employ in period 0 . It is therefore evident that the market-clearing conditions for commodities delivered in 0 entail equality between savings and investments as understood by Garegnani. Hence, Garegnani removes them and introduces a new condition about the ratio in which the two commodities delivered in 0 are demanded, which must, in equilibrium, be equal to the ratio of their initial endowments. He then demonstrates the equivalence of the original system of equilibrium conditions and the system in which the marketclearing conditions for the commodities delivered in 0 are dropped and replaced by the condition about ratios and the condition of equality between savings and investments, defined as stated above.

According to Garegnani, this new way of writing the system of equilibrium conditions reveals the need for an equality between savings and investments in ArrowDebreu models. It follows that even if capital is no longer understood as a factor of production, a condition of equilibrium between the supply of and demand for capital, in-

\footnotetext{
${ }^{23}$ Similar or connected points were raised by other scholars in the period when Garegnani presented his argument. See in particular Schefold (2000, 2003, 2005a and 2005b) and Parrinello (2005, 2008 and 2011).

${ }^{24}$ In Hahn (1982), the commodities are called 'wheat' and 'barley' and the dates are '1976' and '1977'. In Garegnani's articles, the commodities are ' $\mathrm{A}$ ' and ' $\mathrm{B}$ ' and the dates ' 0 ' and ' 1 '. See appendix $\mathrm{A}$ for further details.
} 
tended as the value of commodities saved and invested, still remains in these models. Moreover, Garegnani claims that reverse capital deepening could affect the direction of change of the amount of investments as the (own) rate of interest (of the numéraire commodity) ${ }^{25}$ varies and could, by so doing, cause problems of equilibrium multiplicity and stability. ${ }^{26}$

The neo-Walrasian reaction to this thesis was mainly driven by Michael Mandler, ${ }^{27}$ who attended Garegnani's presentations during the workshop 'General Equilibrium: Problems, Prospects, Alternatives', organised by Fabio Petri in Siena in the summer of 1999. ${ }^{28}$ A few years later, in 2002, within the framework of a symposium in Metroeconomica on the book Critical Essays on Piero Sraffa's Legacy in Economics (Kurz, ed., 2000), he put forward an initial assessment of Garegnani's and Schefold's ${ }^{29}$ contributions. In particular, he concluded that:

Schefold and Garegnani clarify that a convincing Sraffian critique of general equilibrium theory must focus on the stability and plausibility of equilibrium rather than existence. They pursue this project in different ways, Schefold by examining how equilibrium prices move through time when an economy's endowments change, Garegnani by studying the out-of-equilibrium behaviour at a point in time. I have argued that neither strategy succeeds, at least not when the consumer demand side of the model is sufficiently well behaved. [Mandler 2002, p. 220]

In 2005, Metroeconomica organised a second symposium expressly devoted to this controversy with articles by Garegnani, Schefold, Mandler and Parrinello. ${ }^{30}$ On this occasion, referring to the Arrow-Debreu model introduced by Hahn and then taken up by Garegnani, Mandler proved that if household demand functions satisfy, on aggregate,

${ }^{25}$ As is known, in the Arrow-Debreu model, the own factor of interest $\left(1+r_{t, t+1}^{i}\right)$ of a commodity $i$ between two dates, $t$ and $t+1$, is the relative price of this commodity delivered in $t$ in terms of the same commodity delivered in $t+1$. In other words, $p_{t}^{i} / p_{t+1}^{i}=\left(1+r_{t, t+1}^{i}\right)$. As a result, if there are two commodities and two dates of delivery, as in the Hahn-Garegnani model, then there are two own rates of interest. In Garegnani's argument, the own rate of interest of the numéraire commodity (commodity 'B') is treated as an independent variable in order to study how savings and investments react to its variations.

${ }^{26}$ Clearly, if an economy has multiple equilibria, none of them can be globally stable.

${ }^{27}$ Bloise and Reichlin (2009) can also be mentioned.

${ }^{28}$ A collection of the papers presented during the workshop was published in Hahn and Petri (eds) (2003).

${ }^{29}$ Schefold's (2000) argument is quite different from Garegnani's. He starts from a given initial longrun position, an equilibrium in which relative prices remain stationary, and assumes that an increase in the supply of labour takes place through the immigration of workers from abroad. He then introduces a second long-run position in which the higher supply of labour is fully employed but the gross outputs remain unchanged. The intertemporal equilibrium considered by Schefold is the path linking the first long-run position to the second. Schefold's conclusion is that re-switching entails the instability of the intertemporal equilibrium path so conceived because, in the case of re-switching, the use of more labourintensive methods of production would require an increase in the wage rate, whereas the initial excess supply of labour entails a decrease.

30 Parrinello (2005) argued that even though atemporal and intertemporal equilibria are formally equivalent (cf. Malinvaud 1961), the adjustment process needed to achieve the equilibrium price vector is different in the two cases. In his view, this conclusion can open the way to the possibility of instability due to reverse capital deepening. 
the weak axiom of revealed preference (WARP), ${ }^{31}$ then equilibrium multiplicity and instability are (generically) ${ }^{32}$ ruled out independently of any possible hypothesis about the technical coefficients of production. ${ }^{33}$ In other words, problems of multiplicity and instability can only arise in the Hahn-Garegnani model from phenomena concerning households' choices, while firms' decisions, including those about production plans and the employment of inputs, are essentially irrelevant (see Appendix A for some analytical details).

Contrary to what Garegnani had attempted to claim, reverse capital deepening cannot therefore be regarded, in the Arrow-Debreu model, as a possible further cause of equilibrium multiplicity and instability. This conclusion enables us, however, to highlight a fundamental shortcoming of the Arrow-Debreu equilibrium model. As pointed out by Schefold (2007), there is in fact no room for real savings and investments in the ArrowDebreu framework. ${ }^{34}$

As already outlined in section 5, the Arrow-Debreu is a particular kind of neoWalrasian model in which it is assumed that spot and forward markets are: i) complete, i.e. it is possible to exchange all commodities for every possible date of delivery; ii) of finite number, i.e. there is a finite number of possible delivery dates; iii) open simultaneously in a single instant, the initial instant of the first period. The last feature has important implications for the point examined here. On the one hand, given that firms can sell the output they will produce in the same moment as they buy the inputs they will

${ }^{31}$ Let $\mathbf{x}\left(\mathbf{p}^{\prime}\right)$ and $\mathbf{x}\left(\mathbf{p}^{\prime \prime}\right)$ be the bundles of commodities demanded respectively at the price vectors $\mathbf{p}^{\prime}$ and $\mathbf{p}^{\prime \prime}$. If bundle $\mathbf{x}\left(\mathbf{p}^{\prime \prime}\right)$ is also affordable at the price vector $\mathbf{p}^{\prime}$, then the WARP implies that bundle $\mathbf{x}\left(\mathbf{p}^{\prime}\right)$ cannot be affordable at the price vector $\mathbf{p}^{\prime \prime}$. This property always holds if $\mathbf{x}\left(\mathbf{p}^{\prime}\right)$ and $\mathbf{x}\left(\mathbf{p}^{\prime \prime}\right)$ are individual demand functions but can very well be violated in the case of market (aggregate) demand functions. It is also well known that the violation of the WARP on aggregate is due to the combination of households' income effects. For further details, see Mas-Colell, Whinston, and Green (1995, pp. 28-36).

32 While the aggregate WARP cannot rule out equilibrium indeterminacy, it is known that ArrowDebreu economies generally have a finite number of equilibria. See Kehoe (1980) on this point and Fratini (2008) for further considerations.

${ }^{33}$ Mandler's result was not actually new. It had already been proved that the aggregate WARP entails the (generic) uniqueness of equilibrium for Arrow-Debreu economies with constant-returns-to-scale production technology. See Kehoe (1980), Mas-Colell, Whinston, and Green (1995, pp 606-10) and Schefold (1997, pp. 461-70).

${ }^{34}$ In criticising Garegnani's contribution, Schefold remarks that appropriate (and relevant) notions of savings and investments are incompatible with the working of the Arrow-Debreu model. He claims that: '[Garegnani's] approach to the theory of saving is at odds with the conception of intertemporal equilibrium. There is no room for saving as unspent income without a definite commitment to acquire future goods - if necessary, contingent on the state of nature, with uncertainty as in Debreu (1959). Hence there is here no need for a macroeconomic coordination of savings and investment; equilibrium can be found in individual markets. Saving in a world with Keynesian uncertainty, by contrast, is a monetary phenomenon. Markets for future goods are absent. Uncertainty may be a sufficient motive to save in a disequilibrium where not even prices are uniform. Hence, the aggregation of capital to make savers indifferent between capital goods is not necessary for the process of saving to take place, as is clear from Keynesian theory' (Schefold 2007, p. 171). 
employ, costs do not have to be paid in advance by means of capital ${ }^{35}$ but can be financed directly out of revenues. ${ }^{36}$ On the other, since all the markets are open for a single instant, the entire purchasing capacity of households must be used at that moment to buy commodities that will then be delivered on different dates. Saving in order to transfer purchasing power to some future date would thus actually be impossible in the Arrow-Debreu model, as no transaction can take place after the initial instant. It is therefore evident that neither firms' investments nor households' savings can exist in this model if they are understood in the usual (consistent) way. ${ }^{37}$

Moreover, it has been demonstrated (Fratini 2015) that the phenomenon of reswitching, at least as understood in the debate of the 1960s, is not possible in ArrowDebreu models. For re-switching to occur, the link between the interest rate and relative prices must be of the kind that emerges when the latter remain stationary, i.e. the same relative price system applies to both inputs and outputs. If the relative prices of commodities delivered at different dates are instead not stationary, their link with the distributive variables would be relaxed and the coexistence, rather than the reciprocal exclusion, of different methods for the production of the same commodity would become possible.

\section{Saving-Investment equilibrium: part two}

Despite failing to achieve its purpose, Garegnani's attempt was very fruitful. First, as stressed in the final part of the previous section, it brought full awareness that the Arrow-Debreu model is not the right framework to address decisions on investment and

\footnotetext{
${ }^{35}$ If we get rid of the idea that capital is a factor of production, its real role emerges with clarity. As the classical economists and Marx distinctly saw, capital is what allows entrepreneurs to finance the beginning of the production process, to cover all those costs that must be paid in advance of the sale of output and the obtaining of revenues. Revenues, therefore, will allow capitalists to recover the sums paid in advance, but leaving also a profit, that is a surplus of the revenues above the costs.

${ }^{36}$ The impossibility of considering the investment of capital within an Arrow-Debreu economy was argued - perhaps for the first time - by Currie and Steedman (1990, Chapter 7). They claim that meaningful analysis of the investment of capital and its return can be developed only in models with spot markets open at each date. In these models, agents need to trade assets in order to move their purchasing power over time. By contrast, this need is totally absent in the Arrow-Debreu framework, as the idea of transferring wealth over time has no real meaning there (Currie and Steedman 1990, p. 147).

However, Schefold seems to have developed his criticism of Garegnani's analysis independently of the contribution by Currie and Steedman.

${ }^{37}$ Garegnani's very peculiar definition of savings and investments blurred the vision of this fact. Besides, reading a working-paper he published in 2009, it emerges quite clearly that although Garegnani referred his analysis to an Arrow-Debreu model, he argued as if markets opened in each period. He seems to conceive the Arrow-Debreu model as a sort of sequence of temporary equilibrium models and, therefore, he claims that households are subject to as many budget constraints as periods. Clearly, budget constraints would be meaningless if markets were not open and, accordingly, no trade could occur.

Actually, as stressed by Schefold, '[Garegani's (2003)] paper is difficult to read because [...] it provides an idiosyncratic synthesis of heterogeneous elements of different theoretical traditions' (Schefold 2007, p. 130).
} 
saving, as both of these are closely related to the possibility of market trades at different dates. Capital, understood as the amount of value that allows firms to pay for inputs before their outputs are sold, cannot exist if all the transactions, for present and future delivery, take place in the same moment. Second, it paved the way for a better statement of Garegnani's own point. Once it was clear that re-switching and reverse capital deepening cannot be found in the Arrow-Debreu framework, it also became clear that they can instead arise in neo-Walrasian models based on different assumptions.

Even though the relative prices of the commodities delivered in $t$ can in general differ from those of the commodities delivered in $t+1$ in the neo-Walrasian theory, models can be conceived in which, by hypothesis, relative prices remain stationary, one in particular being the model considered by Malinvaud (1953, section IV) and Bliss (1975, chapter 4). Moreover, if chaotic dynamics are excluded, the positions of stationary equilibrium should be precisely those towards which the paths of (sequential) neo-Walrasian equilibrium tend over a sufficiently long period of time. As a result, if the analysis addresses these stationary equilibria, re-switching not only proves to be possible but its role in determining the multiplicity and instability of solutions can also be identified, precisely what was initially and unsuccessfully attempted with reference to the ArrowDebreu equilibrium.

In these models, the stationarity of relative prices period by period requires the absence of accumulation of capital goods (per unit of labour). As a result, the equality between gross savings and the value of the capital goods to replace must be included within the system of conditions for a stationary equilibrium (see Appendix B). This condition has characteristics very similar to the condition of equilibrium between the supply of and demand for capital. In particular, it is expected that the interest rate level will adjust in such a way as to make net accumulation nil, i.e. to bring about equality between gross savings and the value of capital goods employed by firms. ${ }^{38}$ Hicks described this adjustment as follows:

A fall in the rate of interest would encourage the adoption of longer processes, requiring the use (at any moment) of larger quantities of intermediate products. But since we are in a stationary state, there can be no tendency for the stock of capital to increase or diminish; constancy of the stock thus gives us one relation between its size and the rate of interest. Also, if entrepreneurs do not desire to increase or diminish their stock, their net borrowing must be nil. If the demand and supply for loans are to be in equilibrium, net saving must therefore also be nil. The rate of interest must therefore be fixed at a level which offers no incentive for net saving or dis-saving. [Hicks (1939) 1946, pp. 118119.]

At the beginning of the above passage, Hicks claims that a fall in the interest rate would encourage the adoption of more capital-intensive methods of production. This does not always occur, however, as we know that reverse capital deepening is possible. Moreover, re-switching is also possible due to the stationarity of relative prices. The ef-

\footnotetext{
${ }^{38}$ For the sake of simplicity, we can assume that all the capital goods are circulating.
} 
fects of the occurrence of reverse capital deepening and re-switching in the neoWalrasian stationary models are discussed in Fratini (2007) and (2013).

With reference to an overlapping-generation model with linear methods of production and many different kinds of capital goods, the analysis can be focused on stationary equilibria and in particular on the levels of the interest rate ${ }^{39}$ for which the amount of gross savings per worker corresponds to the value of the bundle of (circulating) capital goods employed (per worker). It has been possible to show for this model, that reverse capital deepening can be seen as a further cause of equilibrium multiplicity in addition to income effects. More precisely, multiple equilibria on the rising stretch of the saving function are possible only in the case of reverse capital deepening. Second, on some assumptions of regularity concerning the saving function, ${ }^{40}$ re-switching can determine equilibrium local instability. In other words, with the equilibrium level as the starting point, a small drop in the rate of interest entails an excess of gross savings with respect to the value of the capital goods employed and vice versa.

Garegnani's argument that even though they do not regard capital as a factor of production, neo-Walrasian models are not immune to problems similar to those that emerged in the first stage of the debate therefore ultimately proved correct, albeit in the framework of stationary rather than Arrow-Debreu models.

\section{Conclusions}

As implicitly admitted by Samuelson (1966, p. 582) in writing that there is no unambiguous way to say that one method of production is more capital-intensive than another, capital is not a factor of production and the rate of interest is therefore not the price for its use. This is what was established beyond any reasonable doubt during the first stage of the Cambridge capital controversy. As seen in section 4 , neo-Walrasian ${ }^{41}$ and neoRicardian (Sraffian) economists agree on this point.

\footnotetext{
${ }^{39}$ As is known, assuming the stationarity of relative prices, the wage rate and the price vector, for each technique, can be expressed as functions of the rate of interest.

${ }^{40}$ Savings are typically an amount of value, the difference between income and expenditure in a certain period. However, when an equilibrium is reached, savings are converted, period by period, in the set of capital goods employed. Therefore, if the interest rate slightly increases starting from an equilibrium level, we can assume that the change in the amount of savings is greater than the change in the value of the equilibrium vector of assets (capital goods). Under this assumption, in the model considered in Fratini (2013), instability can only occur in case of re-switching (negative real Wicksell effects).

${ }^{41}$ Some neo-Walrasian authors maintain an ambiguous attitude in this regard. On the one hand, they clearly state, as we have seen, that ' $[\mathrm{t}]$ he rate of interest in not the price of capital' (Bliss 1975, p. 7). On the other, they say that aggregating capital goods in value terms (by means of a given price vector) makes it possible to conceive the 'marginal product' of this aggregate 'capital' and to establish its equality with the rate of interest (see Bliss 1975, pp. 109-10). Is this the same thing as saying that the rate of interest is the price for the use of the aggregate factor 'capital'? If so, then Bliss is contradicting himself. If not, then the equality discussed by Bliss is essentially meaningless.

Another example of the same inconsistency can be found in Dixit (1977).
} 
The disagreement between the two schools regards whether this conclusion also has any impact on the neo-Walrasian supply-and-demand theory of value and distribution. In particular, Bliss and Hahn maintained that the neo-Walrasian theory is not affected by the neo-Ricardian criticism because it regards production as a process employing commodities, i.e. goods and services with date and place of delivery, rather than factors of production.

The response to this claim was primarily developed by Garegnani along two lines. The first is based on the fact that neo-Walrasian equilibrium prices cannot be understood as the central level around which the prices that regulate actual trades tend to orbit. The point therefore concerns the relevance of the neo-Walrasian theory for the interpretation of real economic phenomena. The second instead seeks to show that reverse capital deepening and re-switching can also occur in the neo-Walrasian models, due to the saving-investment market, and affect equilibrium multiplicity and instability.

As regards the second, the analysis initially took the Arrow-Debreu model as its particular point of reference. As argued by Schefold, however, meaningful notions of savings and investments cannot be found within this framework because of the assumption of complete markets open for a single instant. Mandler was thus able to prove that problems of equilibrium multiplicity and instability cannot occur in this model if consumers' decisions are well-behaved, i.e. if they satisfy the WARP on aggregate. More recent studies have shown, however, that problems of multiplicity and instability linked to reswitching can arise in a different class of neo-Walrasian models, namely stationary models characterized by zero net accumulation in each period.

Finally, even though the research is still in progress, there is a conclusion that can surely be drawn from analysis of the first and second stages of the Cambridge capital controversy. Empirical studies claim that in the most industrialised countries, the share of capital incomes in the total national income is in the interval of $25-30 \%$ (see Piketty 2014, p. 222, fig. 6.5). Jevons, Böhm-Bawerk and the other founders of the neoclassi$\mathrm{cal} /$ marginalist approach would say that these capital incomes are what firms pay to households for the use of a factor of production and that their amount therefore depends on the marginal product of 'capital'. Thanks to the first stage of the capital controversy, it is known that this view is 'theoretically unsound', as Hahn put it. It is therefore reasonable to wonder whether the modern mainstream economic theory can provide us with a better explanation of the nature and the determinants of capital incomes. Serious doubts are emerging about this possibility, however, in the second stage of the controversy.

\section{Appendix A: the Hahn-Garegnani model}

The model considered by Hahn (1982) and Garegnani (2000, 2003, and 2011) is an Arrow-Debreu model in which there are two commodities, say $a$ and $b$, and two dates of delivery, 0 and 1 . The initial endowments of the economy include given quantities of 
commodities $a$ and $b$ delivered in 0 and a given quantity of labour to perform during period 0: $\boldsymbol{\omega}=\left[\bar{A}_{0}, \bar{B}_{0}, \bar{L}, 0,0\right] .^{42}$

The endowments of commodities $a$ and $b$ available in 0 are partly consumed directly in that period and partly employed, with labour, in the production of commodities $a$ and $b$ delivered in 1 . In accordance with the customary notation, $\mathbf{y}=\left[-A_{0},-B_{0},-L, A_{1}, B_{1}\right]$ is a production plan. A production plan is technically feasible if and only if it belongs to the production set $Y$. In particular, it can be assumed there are $m$ linear production methods or activities whose technical coefficients are the columns of a $5 \times m$ matrix $\mathbf{M}$. In this case, $Y \equiv\left\{\mathbf{y} \in R^{5}: \mathbf{y}=\mathbf{M v}, \mathbf{v} \in R_{+}^{m}\right\}$, where $\mathbf{v}$ is a vector of activity levels.

On the consumption side, given households' preferences and endowments, their market demand for commodities is a function of the price vector $\mathbf{p}=$ $\left[p_{a 0}, p_{b 0}, w, p_{a 1}, p_{b 1}\right] \in R_{+}^{5}$. To be precise, $\mathbf{x}(\mathbf{p})=\left[x_{a 0}(\mathbf{p}), x_{b 0}(\mathbf{p}), 0, x_{a 1}(\mathbf{p}), x_{b 1}(\mathbf{p})\right]$. The market excess-demand function can also be defined as $\mathbf{z}(\mathbf{p}) \equiv \mathbf{x}(\mathbf{p})-\boldsymbol{\omega}$.

Definition A.1. For this economy, a price vector $\mathbf{p}^{*} \in R_{+}^{5}$ is an equilibrium if and only if: i) $\exists \mathbf{y}^{*} \in Y: \mathbf{z}\left(\mathbf{p}^{*}\right)=\mathbf{y}^{*}$; ii) $\mathbf{p}^{*} \cdot \mathbf{y} \leq 0 \forall \mathbf{y} \in Y$.

Since Arrow and Debreu (1954) proved that at least one equilibrium exists for this model, Hahn's conclusion is that commodity relative prices, own rates of interest which are again commodity relative prices, as $\left(1+r_{a}\right)=p_{a 0} / p_{a 1}$ and $\left(1+r_{b}\right)=$ $p_{b 0} / p_{b 1}$ - and wage rate are determined with no reference to capital as a factor of production.

Garegnani's reply, as stated above, is that reverse capital deepening can be a cause of equilibrium multiplicity in this economy because of the implicit presence of a market for savings and investments. He defines the amount of savings as the value of the part of the initial endowments of commodities that is not directly consumed in period 0: $S(\mathbf{p}) \equiv$ $p_{a 0}\left[\bar{A}_{0}-x_{a 0}(\mathbf{p})\right]+p_{b 0}\left[\bar{B}_{0}-x_{b 0}(\mathbf{p})\right]$. As regards investments, if $A_{0}(\mathbf{p})$ and $B_{0}(\mathbf{p})$ are the inputs of commodities $a$ and $b$ employed, with an amount of labour $\bar{L}$, in order to produce the quantities of outputs $x_{a 1}(\mathbf{p})$ and $x_{b 1}(\mathbf{p})$, in Garegnani's analysis the amount of investment is $I(\mathbf{p}) \equiv p_{a 0} A_{0}(\mathbf{p})+p_{b 0} B_{0}(\mathbf{p})$.

Garegnani then replaces the market clearing conditions for commodities $a$ and $b$ delivered in 0 with the two following conditions: i) $S(\mathbf{p})=I(\mathbf{p})$; ii) $\bar{A}_{0} / \bar{B}_{0}=$ $\left[x_{a 0}(\mathbf{p})+A_{0}(\mathbf{p})\right] /\left[x_{b 0}(\mathbf{p})+B_{0}(\mathbf{p})\right]$. As solutions of Garegnani's modified system are equivalent to solutions of the original system, he claims that reverse capital deepening, by affecting the shape of the investment function, can bring about equilibrium multiplicity.

As can be easily proved for this model, however, if the weak axiom of revealed preference (WARP) holds for the excess-demand function $\mathbf{z}(\mathbf{p})$, then the equilibrium is (generically) unique.

\footnotetext{
${ }^{42}$ There is no need to distinguish between row and column vectors, as these can be identified from their position in the row-by-column multiplication.
} 
Definition A.2. If $\mathbf{p}^{\prime}$ and $\mathbf{p}^{\prime \prime}$ are two price vectors such that $\mathbf{p}^{\prime} \neq \mathbf{p}^{\prime \prime}$, the WARP holds for the excess-demand function $\mathbf{z}(\mathbf{p})$ if $\mathbf{z}\left(\mathbf{p}^{\prime}\right) \neq \mathbf{z}\left(\mathbf{p}^{\prime \prime}\right)$ and $\mathbf{p}^{\prime} \cdot \mathbf{z}\left(\mathbf{p}^{\prime \prime}\right) \leq 0$ imply $\mathbf{p}^{\prime \prime} \cdot \mathbf{z}\left(\mathbf{p}^{\prime}\right)>0$.

Proposition A.1. Let $\mathbf{p}^{\prime}$ and $\mathbf{p}^{\prime \prime}$ be two equilibrium price vectors of the economy. If the WARP holds for the excess-demand function $\mathbf{z}(\mathbf{p})$, then $\mathbf{z}\left(\mathbf{p}^{\prime}\right)=\mathbf{z}\left(\mathbf{p}^{\prime \prime}\right)=\mathbf{y}^{*}{ }^{*}{ }^{4}$

Proposition A.2. Let $\mathbf{p}^{\prime}$ and $\mathbf{p}^{\prime \prime}$ be two equilibrium price vectors of the economy. If the WARP holds for the excess-demand function $\mathbf{z}(\mathbf{p})$, then every price vector $\mathbf{p}^{\prime \prime \prime}=\sigma \mathbf{p}^{\prime}+$ $(1-\sigma) \mathbf{p}^{\prime \prime}$, with $0<\sigma<1$, is an equilibrium price vector. ${ }^{44}$

The second proposition tells us that if improbable cases of equilibrium indeterminacy are ruled out, then an economy whose excess-demand function $\mathbf{z}(\mathbf{p})$ satisfies the WARP has a unique equilibrium independently of any assumption of technical coefficients of production in the matrix $\mathbf{M}$.

\section{Appendix B: the neo-Walrasian stationary model}

In addition to Arrow-Debreu equilibrium, the neo-Walrasian approach includes a number of different models based on different assumptions. We shall focus here on an adapted version of the 'semi-stationary' model studied, among others, by Malinvaud (1953, section IV) and Bliss (1975, chapter 4). ${ }^{45}$ It is a recursive production model in which no initial moment exists and every period is identical to both the previous and the following one.

There are $N$ different commodities. A vector of outputs $\mathbf{q} \in R_{+}^{N}$ emerges at each date from the production processes started in the previous period. The output vector is divided into two parts: $\mathbf{q}=\mathbf{x}+\mathbf{k}$. The vector $\mathbf{x} \in R_{+}^{N}$ is consumed by households during the period. The vector $\mathbf{k} \in R_{+}^{N}$ is made up of the commodities employed as inputs ${ }^{46}$ together

\footnotetext{
${ }^{43}$ Proof: If $\mathrm{p}^{\prime}$ and $\mathrm{p}^{\prime \prime}$ are two equilibrium price vectors, the production plans $\mathrm{y}^{\prime}=\mathrm{z}\left(\mathrm{p}^{\prime}\right)$ and $\mathrm{y}^{\prime \prime}=\mathrm{z}\left(\mathrm{p}^{\prime \prime}\right)$ belong to the set $Y$. As a result, $\mathrm{p}^{\prime} \cdot \mathrm{y}^{\prime \prime} \leq 0$ and $\mathrm{p}^{\prime \prime} \cdot \mathrm{y}^{\prime} \leq 0$. This implies $\mathrm{p}^{\prime} \cdot \mathrm{z}\left(\mathrm{p}^{\prime \prime}\right) \leq 0$ and $\leq 0$. If the WARP holds for the excess-demand function $\mathrm{z}(\mathrm{p})$, however, then this is possible only when $\mathrm{z}\left(\mathrm{p}^{\prime}\right)=\mathrm{z}\left(\mathrm{p}^{\prime \prime}\right)$

${ }^{44}$ Proof: If $\mathrm{p}^{\prime}$ and $\mathrm{p}^{\prime \prime}$ are two equilibrium price vectors, then $\mathrm{p}^{\prime} \cdot \mathrm{y} \leq 0$ and $\mathrm{p}^{\prime \prime} \cdot \mathrm{y} \leq 0$, which implies $\mathrm{p}^{\prime \prime \prime} \cdot \mathrm{y} \leq 0$ $\forall \mathrm{y} \in \mathrm{Y}$.

Moreover, if the WARP holds for the excess-demand function $\mathrm{z}(\mathrm{p})$, then, because of proposition A.1, $\mathrm{z}\left(\mathrm{p}^{\prime}\right)=\mathrm{z}\left(\mathrm{p}^{\prime \prime}\right)=\mathrm{y}^{*}$. Therefore $\mathrm{p}^{\prime} \cdot \mathrm{y}^{*}=\mathrm{p}^{\prime \prime} \cdot \mathrm{y}^{*}=0$, which implies $\mathrm{p}^{\prime \prime \prime} \cdot \mathrm{y}^{*}=0$.

Finally, $\mathrm{z}\left(\mathrm{p}^{\prime}\right)=\mathrm{z}\left(\mathrm{p}^{\prime \prime}\right)=\mathrm{y}^{*}$ and $\mathrm{p}^{\prime \prime \prime} \cdot \mathrm{y}^{*}=0$ imply $\mathrm{p}^{\prime \prime \prime} \cdot \mathrm{z}\left(\mathrm{p}^{\prime}\right)=\mathrm{p}^{\prime \prime \prime} \cdot \mathrm{z}\left(\mathrm{p}^{\prime \prime}\right)=0$. Therefore, if $\mathrm{z}\left(\mathrm{p}^{\prime \prime \prime}\right) \neq \mathrm{z}\left(\mathrm{p}^{\prime}\right)=$ $\mathrm{z}\left(\mathrm{p}^{\prime \prime}\right)=\mathrm{y}^{*}$, then the WARP would imply $\mathrm{p}^{\prime} \cdot \mathrm{z}\left(\mathrm{p}^{\prime \prime \prime}\right)>0$ and $\mathrm{p}^{\prime \prime} \cdot \mathrm{z}\left(\mathrm{p}^{\prime \prime \prime}\right)>0$. This is impossible, however, as it would imply $\mathrm{p}^{\prime \prime \prime} \cdot \mathrm{z}\left(\mathrm{p}^{\prime \prime \prime}\right)=\sigma \mathrm{p}^{\prime} \cdot \mathrm{z}\left(\mathrm{p}^{\prime \prime \prime}\right)+(1-\sigma) \mathrm{p}^{\prime \prime} \cdot \mathrm{z}\left(\mathrm{p}^{\prime \prime \prime}\right)>0$, which is incompatible with Walras's law. Therefore $\mathrm{z}\left(\mathrm{p}^{\prime \prime \prime}\right)=\mathrm{z}\left(\mathrm{p}^{\prime}\right)=\mathrm{z}\left(\mathrm{p}^{\prime \prime}\right)=\mathrm{y}^{*}$

${ }^{45}$ A neo-Walrasian stationary model similar to the one studied here is also considered in Bloise and Reichlin (2009).

${ }^{46}$ For the sake of simplicity, all the capital goods considered in our model are circulating.
} 
with the available labour force $\bar{L}$. The employment of $\mathbf{k}$ and $\bar{L}$ will give a vector of outputs $\mathbf{q}$ in the subsequent period.

On the consumption side, we shall refer to a standard overlapping generation model. $\bar{L}$ identical individuals are born at each date and live for two periods, namely youth and old age. At birth, each individual has no endowment other than a unit of labour services to perform during youth.

Let $\mathbf{p} \in R_{+}^{N}$ be a stationary price vector and $w$ and $r$ respectively the wage rate and the interest rate. Each individual decides on his or her consumption plan so as to maximise his or her intertemporal utility subject to the budget constraint. From consumers' decisions it is possible to obtain the demand function for consumption goods, $\mathbf{x}(\mathbf{p}, w, r)$, with $\mathbf{x}: R_{+}^{N+2} \rightarrow R_{+}^{N}$, and the gross saving function $s(\mathbf{p}, w, r){ }^{47}$

On the production side, let $\mathbf{A}$ and $\ell$ be respectively the $N \times N$ matrix of commodity input coefficients and the $N \times 1$ vector of labour input coefficients. Given the technical coefficients $(\mathbf{A}, \ell)$, the labour force of the economy $\bar{L}$ and the functions $\mathbf{x}(\mathbf{p}, w, r)$ and $s(\mathbf{p}, w, r)$, the equilibrium conditions can be set for our stationary model.

Definition B.1. For this economy, an output vector $\mathbf{q}^{*} \in R_{+}^{N}$, a price vector $\mathbf{p}^{*} \in R_{+}^{N}$, a wage rate $w^{*}$ and an interest rate $r^{*}$ are a stationary equilibrium if and only if the following obtain:

i) market clearing conditions

$$
\begin{aligned}
& \mathbf{x}\left(\mathbf{p}^{*}, w^{*}, r^{*}\right)=\mathbf{q}^{*} \cdot(\mathbf{I}-\mathbf{A}) \\
& \mathbf{q}^{*} \cdot \ell=\bar{L}
\end{aligned}
$$

ii) zero-profit conditions

$$
\mathbf{p}^{*}-\mathbf{A} \cdot \mathbf{p}^{*}\left(1+r^{*}\right)-\ell w^{*}=0
$$

iii) a zero-net-accumulation condition

$$
s\left(\mathbf{p}^{*}, w^{*}, r^{*}\right)-\mathbf{q}^{*} \cdot \mathbf{A} \cdot \mathbf{p}^{*}=0 .
$$

Once a numéraire is adopted, i.e. price vectors are normalised, the zero-profit conditions allow us to express the price vector and the wage rate as functions of the rate of interest. Therefore, in turn, the LHS of the zero-net-accumulation condition becomes a function of the rate of interest and we can look for the interest rate levels that make the net accumulation zero.

It has been proved (Fratini 2007 and 2013) that if alternative methods of production for the same commodity are allowed, re-switching is possible and can affect the shape of the net-accumulation function so as to cause equilibrium multiplicity and instability.

\footnotetext{
${ }^{47}$ In this model, as there is no saving by elderly people for clearly evident reasons, the total amount of gross savings in each period corresponds to the difference between the income and consumption expenditure of the young.
} 


\section{References}

Arrow, K.J. and Debreu, G. (1954). 'Existence of an equilibrium for a competitive economy.' Econometrica, 22(3), 265-290.

Bliss, C.J. (1970). 'Comment on Garegnani.' Review of Economic Studies, 37(3), 437-438.

Bliss, C.J. (1975). Capital Theory and Distribution of Income. Amsterdam/New York: North-Holland/Elsevier.

Bloise, G. and Reichlin, P. (2009). 'An obtrusive remark on capital and comparative statics.' Metroeconomica, 60(1), 54-76.

Bruno, M., Burmeister, E., and Sheshinski, E. (1966). 'The nature and implications of the reswitching of techniques.' Quarterly Journal of Economics, 80(4), 526-553.

Champernowne, D.G. (1953-54). 'The Production Function and the Theory of Capital: A Comment.' Review of Economic Studies, 21(2), 112-135.

Currie, M. and Steedman, I. (1990). Wrestling with Time. Problems in Economic Theory. Manchester: Manchester University Press.

Debreu, G. (1959). Theory of Value. New York: Wiley.

Dixit, A. (1977). 'The Accumulation of Capital Theory.' Oxford Economic Papers, 29(1), 1-29.

Fratini, S.M. (2007). 'Reswitching of techniques in an intertemporal equilibrium model with overlapping generations.' Contributions to Political Economy, 26(1), 43-59.

Fratini, S.M. (2008). 'Economic generality versus mathematical genericity: Activitylevel indeterminacy and the index theorem in constant returns production economies.' Metroeconomica, 59(2), 266-275.

Fratini, S.M. (2013). 'Real Wicksell effect, demand for capital and stability.' Metroeconomica 64(2), 346-360.

Fratini, S.M. (2015). 'A note on reswitching and intertemporal prices.' Review of Political Economy, 27(4), 666-678.

Fratini, S.M. (2017). Neoclassical theories of stationary relative prices and the supply of capital. MPRA Paper n. 76343.

Garegnani, P. (1966). 'Switching of Techniques.' Quarterly Journal of Economics, 80(4), 554-567.

Garegnani, P. (1970a). 'Heterogeneous capital, the production function and the theory of distribution.' Review of Economic Studies, 37(3), 407-436.

Garegnani, P. (1970b). ‘A Reply.' Review of Economic Studies, 37(3), 439. 
Garegnani, P. (1976). 'On a change in the notion of equilibrium in recent work on value and distribution.' In M. Brown, K. Sato, and P. Zarembka (eds): Essays in Modern Capital Theory. Amsterdam: North-Holland, pp. 25-45.

Garegnani, P. (1983). 'Two Routes to Effective Demand: Comment on Kregel.' In J.A. Kregel (ed.): Distribution, effective demand and international economic relations. London and Basingstoke: Macmillan, pp. 69-80.

Garegnani, P. (1990). 'Quantity of capital.' In J. Eatwell, M. Milgate, and P. Newman (eds): The New Palgrave: Capital Theory. London: Macmillan, pp. 1-73.

Garegnani, P. (2000). 'Savings, Investment and the Quantity of Capital in a System of General Intertemporal Equilibrium.’ In H.D. Kurz (ed.), pp. 392-445.

Garegnani, P. (2003). 'Savings, Investment and Capital in a System of General Intertemporal Equilibrium.' In F.H. Hahn and F. Petri (eds), pp. 117-172.

Garegnani, P. (2005a). 'Capital and intertemporal equilibria: a reply to Mandler.' Metroeconomica, 56(4), 411-437.

Garegnani, P. (2005b). 'Further on capital and intertemporal equilibria: a rejoinder to Mandler.' Metroeconomica, 56(4), 495-502.

Garegnani, P. (2010). 'Capital in the Neoclassical Theory. Some Notes and a "Reply to professor Bliss's comment." In A. Birolo, D. Foley, H.D. Kurz, B. Schefold, and I. Steedman (eds): Production, Distribution and Trade: Alternative Perspectives. London: Routledge, pp. 77-100.

Garegnani, P. (2011). 'Savings, investment and capital in a system of general intertemporal equilibrium.' In R. Ciccone, C. Gehrke, and G. Mongiovi (eds): Sraffa and Modern Economics. London: Routledge, pp. 13-74.

Garegnani, P. (2012) 'On the present state of the capital controversy.' Cambridge Journal of Economics, 36(6), 1417-1432.

Geanakoplos, J. (1987). 'Arrow-Debreu model of general equilibrium.' In J. Eatwell, M. Milgate, and P. Newman (eds): The New Palgrave Dictionary of Economics, vol. I. London: Macmillan, pp. 116-124.

Gehrke, C. (2003). 'On the Transition from Long-period to Short-period Equilibria.' Review of Political Economy, 15(1), 85-106.

Hahn, F.H. (1975). 'Revival of political economy: the wrong issues and the wrong argument.' Economic Record, 51(3), 360-364.

Hahn, F.H. (1982). 'The neo-Ricardians.' Cambridge Journal of Economics, 6(4), 353-362.

Hahn, F.H. and Petri, F. (eds) (2003). General Equilibrium. Problems and Prospects. London: Routledge.

Hicks, J.R. (1932). Theory of Wages. London: Macmillan. 
Hicks, J.R. ([1939] 1946). Value and Capital: An Inquiry into Some Fundamental Principles of Economic Theory. Oxford: Clarendon Press.

Hicks, J.R. (1960). 'Thoughts on the Theory of Capital. The Corfu Conference.' Oxford Economic Papers, 12(2), 123-132.

Hicks, J.R. (1965). Capital and Growth. Oxford: Clarendon Press.

Lazzarini, A. (2015). 'Some unsettled issues in a second phase of the CambridgeCambridge controversy.' Review of Radical Political Economics, 47(2), 256-273.

Levhari, D. (1965). 'A non-substitution theorem and switching of techniques.' Quarterly Journal of Economics, 79(1), 98-105.

Lutz, F.A. and Hague, D.C. (eds) (1961). The Theory of Capital. Proceedings of a conference held by the International Economic Association. London: Macmillan.

Kaldor, N. (1937). 'Annual survey of economic theory: The recent controversy on the theory of capital.' Econometrica, 5(3), 201-233.

Kehoe, T.J. (1980). 'An index theorem for general equilibrium models with production.' Econometrica, 48(5), 1221-1232.

Kurz, H.D. (ed.) (2000). Critical Essays on Piero Sraffa's Legacy in Economics. Cambridge University Press: Cambridge.

Kurz, H.D. and Salvadori, N. (2003). "Classical" vs "Neoclassical” theories of value and distribution and the long-period method.' In F.H. Hahn and F. Petri (eds), pp. 216-245.

Malinvaud, E. (1953). 'Capital Accumulation and Efficient Allocation of Resources.' Econometrica, 21(2), 233-268.

Malinvaud, E. (1961). 'The Analogy Between Atemporal and Intertemporal Theories of Resource Allocation.' Review of Economic Studies, 28(3), 143-160.

Mandler, M. (2002). 'Classical and Neoclassical Indeterminacy in One-shot Versus Ongoing Equilibria.' Metroeconomica, 53(3), 203-222.

Mandler, M. (2005). 'Well-behaved production economies.' Metroeconomica, 56(4), 477-494.

Marshall, A. ([1890] 1920). Principles of Economics. London: Macmillan.

Mas-Colell, A., Whinston, M.D., and Green, J.R. (1995). Microeconomic Theory. New York and Oxford: Oxford University Press.

Milgate, M. (1979). 'On the origin of the notion of "intertemporal equilibrium." Economica, 46(181), 1-10.

Morishima, M. (1966). 'Refutation of the non-switching theorem.' Quarterly Journal of Economics, 80(4), 520-525.

Parrinello, S. (2005). 'Intertemporal competitive equilibrium, capital and the stability of tâtonnement pricing revisited.' Metroeconomica, 56(4), 514-531. 
Parrinello, S. (2008). The stability of general intertemporal equilibrium: a note on Schefold.' Metroeconomica, 59(2), 305-312.

Parrinello, S. (2011). 'The market for saving in the theory of general intertemporal equilibrium.' In N. Salvadori and C. Gehrke (eds): Keynes, Sraffa and the Criticism of Neoclassical Theory. London: Routledge, pp. 313-329.

Pasinetti, L.L. (1966). 'Changes in the rate of profit and switches of techniques.' Quarterly Journal of Economics, 80(4), 503-517.

Petri, F. (1978). 'The difference between long-period and short-period general equilibrium and the capital theory controversy.' Australian Economic Papers, 17(31), 246-260.

Petri, F. (1991). 'Hick's recantation of the temporary equilibrium method.' Review of Political Economy, 3(3), 268-288.

Petri, F. (2004). General Equilibrium, Capital and Macroeconomics: A Key to Recent Controversies in Equilibrium Theory. Cheltenham: Edward Elgar.

Petri, F. (2017). 'The Passage of Time, Capital, and Investment in Traditional and in Recent Neoclassical Value Theory.' CEconomia, 7(1), 111-140.

Piketty, T. (2014). Capital in the Twenty- First Century. Cambridge (Mass.) and London: Harvard University Press.

Robinson, J. (1953). 'The Production Function and the Theory of Capital.' Review of Economic Studies, 21(2), 81-106.

Samuelson, P.A. (1961). 'A New Theorem on Nonsubstitution.' In H. Hegeland (ed.): Money, Growth, and Methodology and other Essays in Economics in Honor of Johan Åkerman. Lund: CWK Gleerup, pp. 407-423.

Samuelson, P.A. (1962). 'Parable and realism in capital theory: the surrogate production function.' Review of Economic Studies, 29(3), 193-206.

Samuelson, P.A. (1966). 'A summing up.' Quarterly Journal of Economics, 80(4), 568583.

Schefold, B. (1997). Normal Prices, Technical Change and Accumulation. London: Macmillan.

Schefold, B. (2000). 'Paradoxes of capital and counter-intuitive changes of distribution in an intertemporal equilibrium model.' In H.D. Kurz (ed.), pp. 363-391.

Schefold, B. (2003). 'Applications of the Classical Approach.' In F.H. Hahn and F. Petri (eds), pp. 440-467.

Schefold, B. (2005a). 'Reswitching as a cause of instability of intertemporal equilibrium.' Metroeconomica, 56(4), 438-476.

Schefold, B. (2005b). 'Zero wages - no problem? a reply to Mandler.' Metroeconomica, 56(4), 503-513. 
Schefold, B. (2007). 'Savings, investment and capital in a system of general intertemporal equilibrium - an extended comment on Garegnani with a note on Parrinello.' In G. Chiodi and L. Ditta (eds): Sraffa or An Alternative Economics. Basingstoke: Palgrave-Macmillan, pp. 127-184.

Shove, G. (1933). 'Review of J.R. Hicks, The Theory of Wages, 1932.' Economic Journal, 43(171), 460-473.

Sraffa, P. (1932). 'Dr. Hayek on money and capital.' Economic Journal, 42(165), 42-53.

Sraffa, P. (1960). Production of Commodities by Means of Commodities. Prelude to a Critique of Economic Theory. Cambridge: Cambridge University Press. 
Author contact information:

Saverio M. Fratini

Department of Economics

Roma Tre University

Via Silvio D'Amico, 77

00145 - Rome (Italy)

saveriomaria.fratini@uniroma3.it 